\title{
Growing roses without chemicals: transitioning the collection at Auckland Botanic Gardens (New Zealand) 2000-2020
}

\author{
Emma Bodley', Paula Lollback², Jack Hobbs³, Mere Brewer ${ }^{4}$ \& Rebecca Stanley ${ }^{5}$
}

\begin{abstract}
The Rose Garden at Auckland Botanic Gardens displays rose cultivars which perform well and remain healthy in Auckland, New Zealand, without pesticide applications. Miticides, insecticides and fungicides are not used. Suitable cultivars are chosen for public display to inspire gardeners and encourage visitors to make their own rose selections based on personal preferences from an array of proven performers. These are identified to the public as 'Star Performers.' Here the process of trialling, identifying and displaying old shrub and modern rose cultivars that have achieved Star Performer status over the past 20 years is presented. This work demonstrates the role that botanic gardens can play in promoting sustainable horticultural practices.
\end{abstract}

\section{Introduction}

Roses have a reputation of being difficult to grow and requiring chemicals to ensure plant health. Many public gardens in New Zealand maintain a regular chemical spray regime. However, worldwide the trend towards chemical-free, low-input or low-maintenance roses is growing (Mackay et al., 2008). The use of genetic tools to investigate disease resistance to improve breeding will have an increasing impact in this area (Debener \& Byrne, 2014), assisted by the recent sequencing of the rose genome (Smulders et al., 2019). Several schemes based in the USA, such as the American
Rose Trials for Sustainability programme (American Rose Trials for Sustainability ${ }^{\circledR}$, n.d.) and Earth-Kind Roses (Aggie Horticulture, n.d.), promote roses that do not require chemical applications to perform well. Some rose gardens and public gardens, such as New York Botanic Garden, have shifted their rose collections to include more sustainable chemical-free cultivars (Kukielski, 2015).

At Auckland Botanic Gardens (ABG) we promote plants to our visitors and home gardeners that do not require chemicals to enable them to grow well. In 2000 we ceased the use of chemicals in the rose collection and progressively culled all poorly

\footnotetext{
${ }^{1}$ Emma Bodley is Botanical Records and Conservation Specialist at Auckland Botanic Gardens.

Address: 102 Hill Road, Manurewa, Auckland, New Zealand.

Email: emma.bodley@aucklandcouncil.govt.nz

2 Paua Lollback is Collection Curator at Auckland Botanic Gardens.

Address: as above.

${ }^{3}$ Jack Hobbs is Manager at Auckland Botanic Gardens.

Address: as above.

${ }^{4}$ Mere Brewer is Senior Gardener Collections at Auckland Botanic Gardens.

Address: as above.

${ }^{5}$ Rebecca Stanley is Principal Advisor, Conservation Partnerships, at Auckland Council.

Address: 135 Albert Street, Auckland, New Zealand.
} 
performing roses to identify those that could be recommended as low maintenance and spray-free.

Plant trials, supported by the promotion of plant health to ensure self-sustaining collections with minimal intervention, are the basis of sustainable gardening practices at $A B G$. The management goals for trial and research collections are:

- to inform plant selection and publicise recommendations

- $\quad$ to influence the range of plants grown in the Auckland region

- to inform content in our own themed plant collections and visitor centre displays.

Assessment of all plants on an ongoing basis is used to select disease-free plants to build the collection as well as to recommend those we determine as outstanding performers (known as Star Performers) to the public. There is a trial ground at ABG where most trials are undertaken, with an additional Rose Trial bed in the Rose Garden. However, by their nature trials are ongoing and plants throughout the collections are still considered to be under trial. Plants must earn their place and then continue to prove their merit.

\section{Sustainable horticultural practices at Auckland Botanic Gardens}

In addition to trialling plants to assess their suitability to Auckland's climate, ABG's horticulturists implement cultivation practices that support plant health and promote abundant life without reliance on fungicides or insecticides. Agrichemicals may have an adverse effect on water quality, soil microbiota and fauna, have non-target impacts on beneficial organisms and affect human health.
We aim to establish communities of plants that are self-sustaining with minimal intervention. Soil health is paramount to plant health, and cultivation practices ensure an abundance of beneficial soil micro-organisms whose competitive activities may suppress soil-borne pathogens. Other practices that support beneficial organisms include minimal soil disturbance as well as the application of compost and organic mulch. Only organically derived, non-synthetic fertilisers are used. Adequate plant spacing, companion planting and planting at the most suitable time of year for the species also support plant health.

In addition to the environmental benefits of sustainable horticultural practices, they are a way to protect visitor safety with the reduction of chemical use. The ideal conditions to apply agrichemicals coincide with days of highest visitor numbers (windless and fine) in a public garden; not using agrichemicals therefore ensures visitor safety is not put at risk.

\section{The Rose Garden at Auckland Botanic Gardens}

The first rose collection at ABG was established in 1981 and was on display for the opening of the gardens to the public in 1982 (Fig. 1). By 1989, the Rose Garden had expanded to include the Auckland Rose of the Year trials in partnership with the Rose Introducers of New Zealand (RINZ). The number of rose plants ultimately exceeded 6,000. This collection became known as the 'RINZ Trials' and comprised a monoculture of modern, newly released cultivars owned by RINZ which required a regular chemical spray regime to support them throughout the growing season (Fig. 2). Common pests and diseases of roses include black spot (Diplocarpon rosae), powdery mildew (Sphaerotheca pannosa var. rosae), 


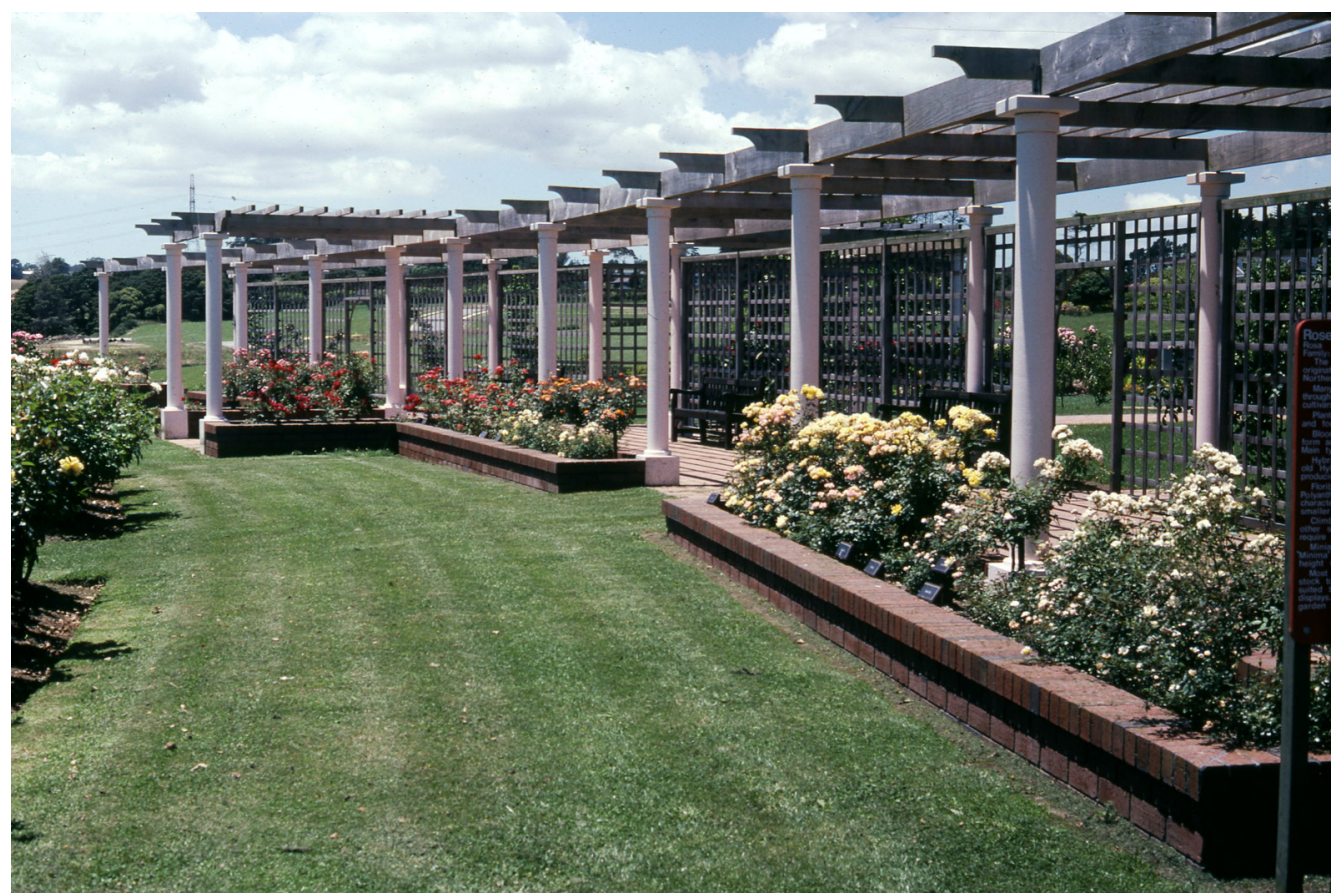

Fig. 1 The first Rose Garden in 1985. Photo: Auckland Botanic Gardens.

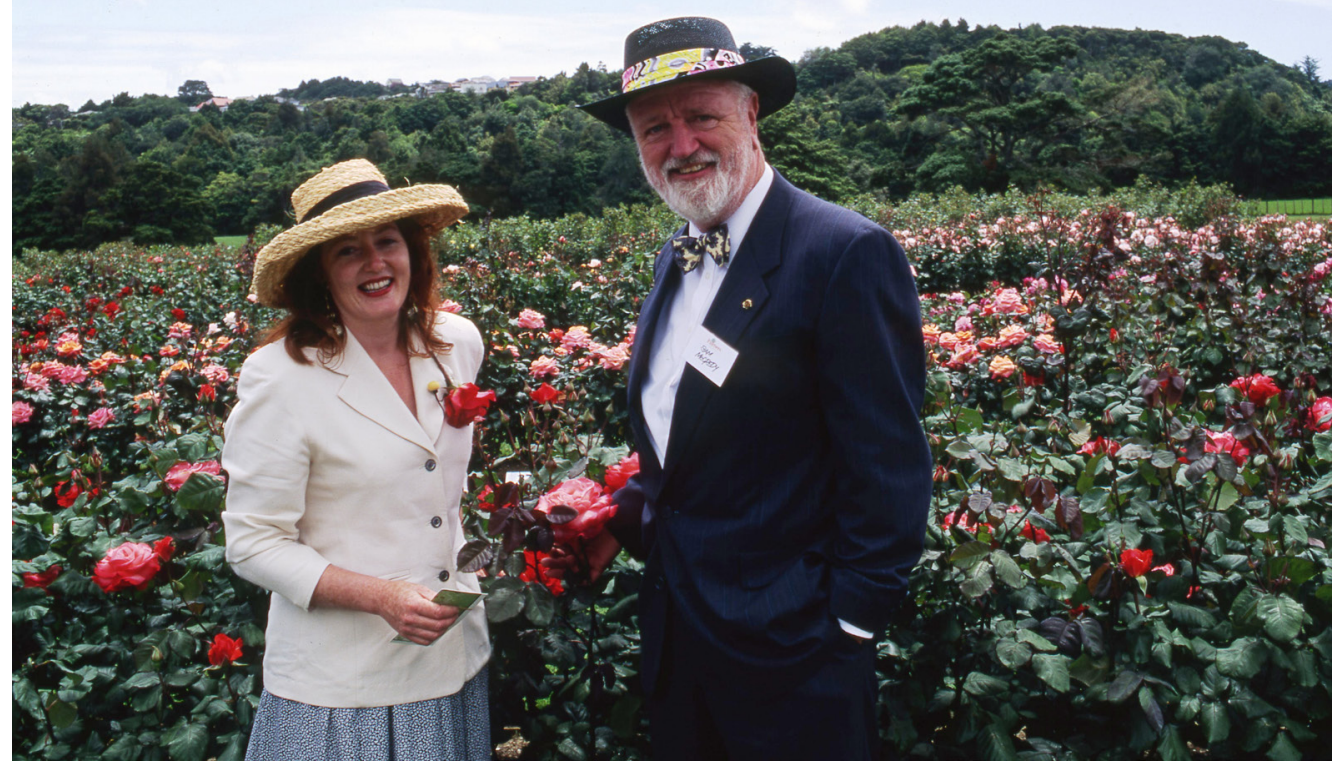

Fig. 2 A RINZ evaluation day in 1992 with Sam McGredy and Maggie Barry. Photo: Auckland Botanic Gardens. 
rust (multiple species of Phragmidium), scale insects (Hemiptera: Sternorrhyncha) and mites (the European red spider mite Panonychus ulmi and the two-spotted spider mite Tetranychus urticae).

A typical pesticide regime recommended by ABG for a home gardener at this time was the use of Supershield ${ }^{\circledast}$ (myclobutanil and tau-fluvalinate), Guardall ${ }^{\circledR}$ (chlorothalonil, thiophanate-methyl and tau-fluvalinate) or Greengard ${ }^{\oplus}$ (chlorothalonil and thiophanatemethyl) (Grant \& Flint, 1998). These were to be applied at two- to three-week intervals from September to May. Pruning (in June) was to be followed by three applications of copper and oil.

A trial was carried out by Grant \& Flint (1998), comparing the health of roses with no pesticides, based on the existing regime at $A B G$, and that of roses treated with a commercial regime such as the one recommended above. They deduced that 'there was no need for the commercial regime' and that an 'acceptable result' could be achieved from reduced spraying. At $A B G$, we would define an 'acceptable result' as having minimal to no pests or diseases throughout the growing season. Current trials at $A B G$ quantify each pest and disease found on a plant by the percentage of the plant affected by that pest or disease; this provides information throughout the season of what pest or disease is present and how much it is impacting the plant.

By the year 2000, the concept of sustainable horticulture was being developed at $A B G$ and the decision was made to reduce applications of pesticides. The RINZ Trials were discontinued at this time because of the development of sustainable horticultural practices that no longer aligned with RINZ practices. The Rose Garden was relocated and redesigned, and in 2001 comprised five separate themed areas: the Historic Rose Garden, the Reflective Rose Garden, the New Zealand Rose Garden, the Rose Gallery and the Trial Beds. These areas are described below.

\section{Historic Rose Garden}

The Historic Rose Garden contains species roses and heritage roses, including some that were introduced to New Zealand in colonial times, as well as some English roses that complement the old-fashioned look and feel (Fig. 3). These are mixed with perennials, annuals and shrubs in a cottage garden style evocative of an early settler's garden. Special consideration is given to roses of historical significance such as Rosa 'Slater's Crimson China', thought to be the first ornamental plant introduced to New Zealand.

\section{Reflective Rose Garden}

This is a formal display garden containing mainly climbing and floribunda roses with some shrub roses. Roses are grouped according to flower colour, from pastels to bright shades (Fig. 4). The garden displays symmetry in its layout and structure.

\section{New Zealand Rose Garden}

This garden contains a mix of recommended garden roses intermingled with predominantly New Zealand native plants that showcase the beauty of both (Fig. 5). The native plants chosen have attractive foliage, texture and form which complement and combine well with roses. Some other exotic plants are included, with self-sown violas and aquilegias for seasonal colour.

\section{The Rose Gallery}

The Rose Gallery displays a range of roses that have performed best in our trials. These are supported by low-maintenance plants which do not compete with roses. 


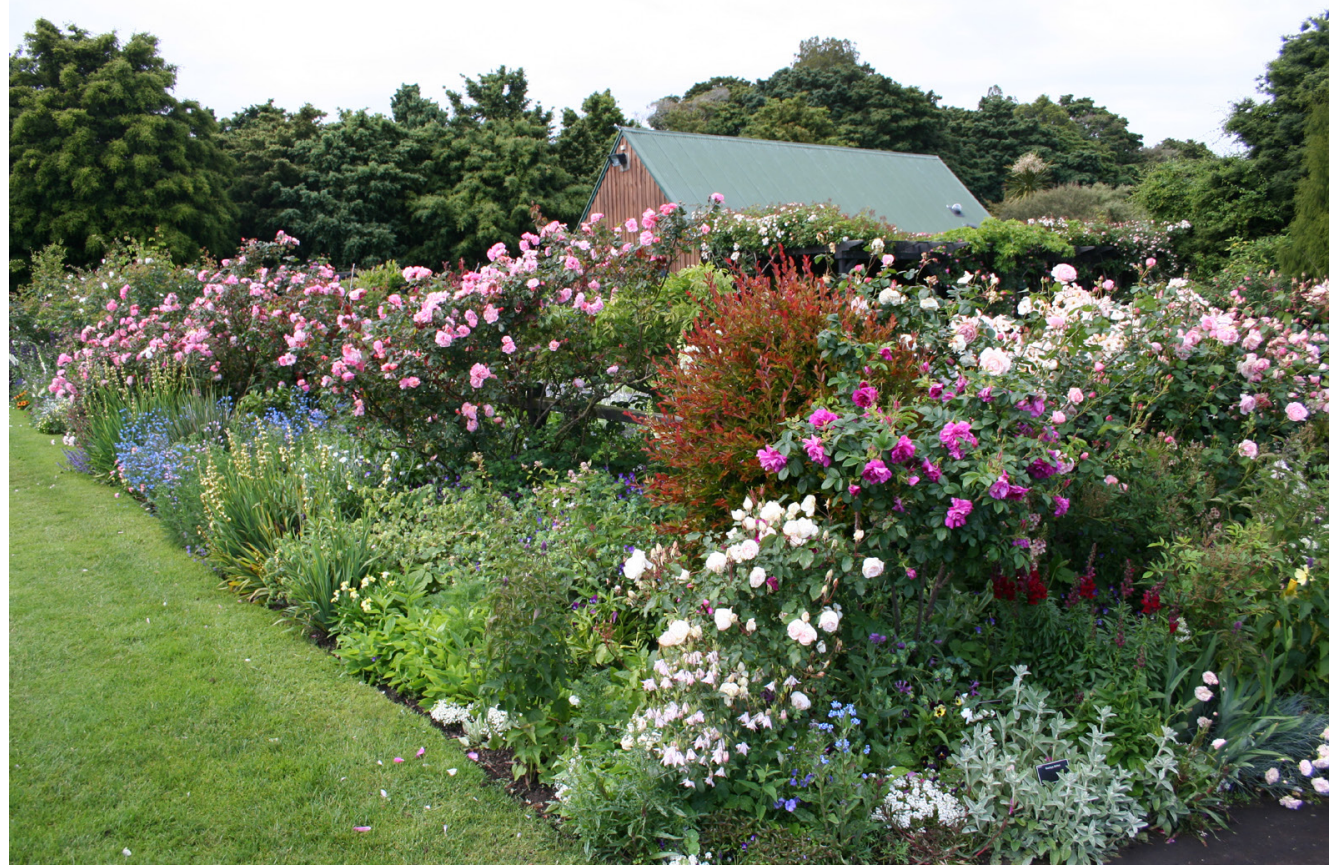

Fig. 3 The Historic Rose Garden. Photo: Auckland Botanic Gardens.

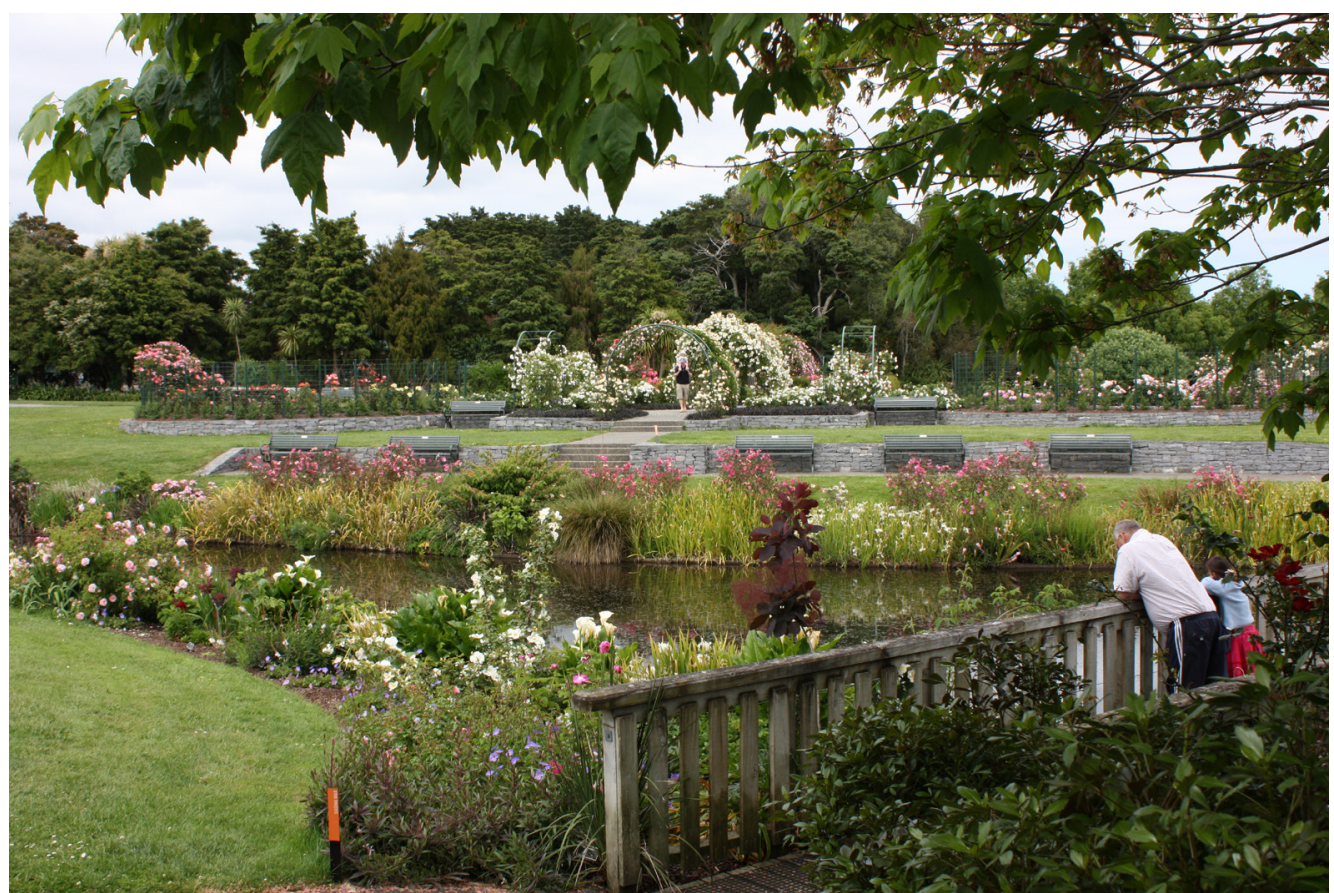

Fig. 4 The Reflective Rose Garden. Photo: Auckland Botanic Gardens. 


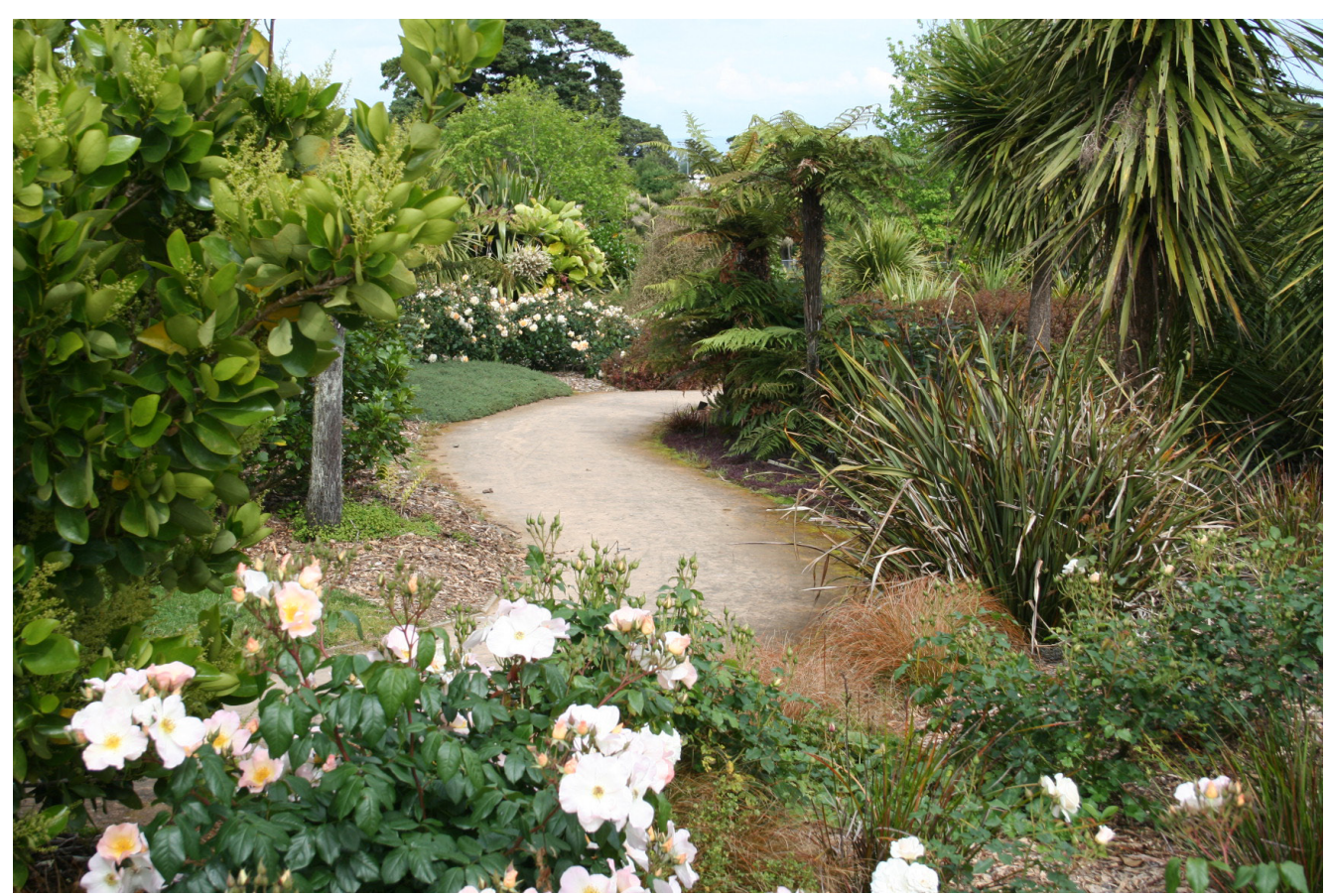

Fig. 5 The New Zealand Rose Garden. Photo: Auckland Botanic Gardens.

\section{The Trial Beds}

New roses are introduced to these beds to be tested for their performance in Auckland conditions. Candidates for trial are prioritised to those cultivars produced by breeders that focus on disease resistance. All-new rose accessions (i.e. those that have not previously been evaluated at $A B G$ ) are first planted in the Trial Beds.

\section{Rose assessment}

Roses are evaluated for their performance and overall health over a minimum of 12 months and longer if necessary. Particular attention is paid to the evaluation of modern cultivars, although some species and heritage types may also be included. Those cultivars that perform well and remain healthy over 1-2 years generally graduate to the Rose Gallery for final confirmation of performance (across several years), and thereafter are promoted to other display beds. Rose cultivars will be culled if considered too disease-prone, or if they are regarded as having insufficient ornamental merit. The primary assessment criterion is pest and disease resistance; however other characteristics are considered, including their amenity value, abundance and quality of flowers, fragrance and habit.

Roses that are exceptional are labelled as 'Star Performers'; to receive this accolade, a rose must produce clusters of flowers over a long period of time and not require spraying for pests and diseases. These plants will have received a 9 or 10 in the overall rating. A second layer of plants with proven performance are defined as 'Recommended Plants'. These plants have consistently performed to high standards in suitable conditions in Auckland and have received an 8 as their overall rating. It is worth noting that there are cases when a cultivar is kept in the 
collection despite a lower rating, normally if it has conservation or historical significance, as per our Plant Collection Guidelines.

$A B G$ may also be the only place in New Zealand that holds a particular cultivar, and cultivar conservation is just as important as threatened species conservation. The rating system is primarily for providing advice to the public about plant selection, and although it informs the selection of plants for our display gardens it is not the only mechanism for driving plant selection. Conservation and research specimens are equally important for botanic gardens to incorporate into their collections.

Over 570 cultivars were included in the RINZ Trials during the time they were at ABG, with between 50 and 200 cultivars added to the trial annually. With the loss of specialist rose nurseries, there are far fewer roses being introduced to the market. Between 10 and 20 new roses are available each year, which has significantly reduced the numbers trialled at ABG. However, over 400 cultivars are displayed at $A B G$, which provides plenty of choice for every gardener.

Table 1 in the Appendix presents results from summer surveys of flowering and pest and disease occurrence. Flowering records were taken weekly, although with Covid-19 lockdowns and other restrictions, there were a few weeks between 31 December 2020 and 15 January 2021, and between 6 February 2021 and the end of March 2021, when the survey could not be carried out. A complete flowering period was therefore not collated. Flowering records ceased at the end of February 2021. Despite this setback the data do provide a good indicator of flowering period. Pest and disease observations were made twice during the season, in October 2020 and late January 2021. The percentage of a pest or disease observed was recorded as the percentage of the plant affected. Any pest or disease with an incidence of over 20 per cent observed has been noted in Table 1 in the Appendix. Fewer pests and diseases were seen in October compared to January when conditions were more humid. Overall ratings were assessed during peak flowering in early December 2020. Some cultivars were not given ratings for one of a number of reasons:

- They were not yet flowering.

- They were not growing in ideal conditions; for example, the soil conditions were poor or plants had insufficient space due to crowding.

- They had been recently pruned.

Cultural practices in the Rose Garden mirror sustainable horticulture practices applied throughout ABG. Curators of the Rose Garden ensure plants are well spaced to ensure adequate airflow and reduce the humidity preferred by fungi. Pruning takes place in June each year, which ensures healthy growth and promotes plants shaped to maximise airflow. Rose monocultures are avoided, with preference given to a diverse range of companion plantings. Companion plantings can comprise perennials or annuals and species native to New Zealand, to ensure habitats for predatory insects which can assist in controlling any pests and diseases that may occur.

\section{Conclusion}

Eighteen rose cultivars are promoted as Star Performers on leaflets and on our Plants for Auckland website database (Auckland Botanic Gardens, 2020), and a further 41 are Recommended Plants. Star Performers are mainly floribunda or shrub-type roses. This study has shown that a wide range of roses can be grown in Auckland without the 
use of chemicals, and the authors believe that chemical-free cultivation supports a healthier garden. Star Performers help ensure Auckland gardeners have success with their plant selection, and although this forms the backbone of our plant collections, consideration is also given to roses of conservation or historical significance in order to meet our core role in plant conservation.

\section{Acknowledgements}

We would like to thank Christine Low and Karah Lockman for collecting flowering records.

\section{References}

AGGIE HORTICULTURE (N.D.). Earth Kind Roses. Available online: https://aggie-horticulture.tamu. edu/earthkindroses (accessed May 2020).

\section{AMERICAN ROSE TRIALS FOR SUSTAINABILITY ${ }^{\circledR}$}

(N.D.). What we do. Available online: www. americanrosetrialsforsustainability.org (accessed May 2020).

\begin{abstract}
AUCKLAND BOTANIC GARDENS (2020).
Plants for Auckland. Available online: www. aucklandbotanicgardens.co.nz (accessed May 2020).

DEBENER, T. \& BYRNE, D.H. (2014). Disease resistance breeding in rose: current status and potential of biotechnological tools. Plant Science, 228: 107-117. doi: https://doi.org/10.1016/j. plantsci.2014.04.005
\end{abstract}

GRANT, D. \& FLINT, T. (1998). Rose spraying trial. The New Zealand Rose Annual: 56-58.

KUKIELSKI, P.E. (2015). Roses Without Chemicals: 150 Disease-Free Varieties That Will Change the Way You Grow Roses. Timber Press, Portland, OR.

MACKAY, W.A., GEORGE, S.W., MCKENNEY, C., SLOAN, J.J., CABRERA, R.I., REINERT, J.A., COLBAUGH, P., LOCKETT, L. \& CROW, W. (2008). Performance of garden roses in north-central Texas under minimal input conditions. HortTechnology, 18(3): 417-422. doi: https://doi.org/10.21273/ HORTTECH.18.3.417

SMULDERS, M.J., ARENS, P., BOURKE, P.M., DEBENER, T., LINDE, M., DE RIEK, J., LEUS, L., RUTTINK, T., BAUDINO, S., SAINT-OYANT, L.H. \& CLOTAULT, J. (2019). In the name of the rose: a roadmap for rose research in the genome era. Horticulture Research, 6(1): 1-17. doi: https://doi. org/10.1038/s41438-019-0156-0

\section{Appendix}

Table 1 Summary information for 256 roses from flowering season 2020-2021.

DNR = did not rate because the plant was not in flower or had been cut back. The incidence of pests and diseases is shown as a percentage, and the month in which the plant produced flowers is indicated with an X. Star Performers, with a rating of 9 or 10 , are indicated with two asterisks $\left(^{* *}\right)$ and Recommended Plants, with a rating of 8 , are indicated with three $\left(^{* * *}\right)$. The flowering period is indicative only. A rating of 8 or higher means that the plant remains in the collection. If it achieved a lower score, historical significance as a cultivar or conservation value is considered before culling.

\begin{tabular}{|c|c|c|c|c|c|c|c|}
\hline \multirow[t]{2}{*}{ Name } & \multirow[t]{2}{*}{ Rating } & \multirow[t]{2}{*}{ Pests and diseases } & \multicolumn{5}{|c|}{ Flowering period } \\
\hline & & & Oct & Nov & Dec & Jan & Feb \\
\hline Rosa Absolutely Fabulous & $8^{* * *}$ & & $x$ & $x$ & $x$ & $x$ & $x$ \\
\hline Rosa 'Aglaia' & $8^{* * *}$ & & $x$ & & & & \\
\hline Rosa'Alain Blanchard' & 7 & & & & & & \\
\hline Rosa Albéric Barbier & $8^{* * *}$ & & $x$ & $x$ & $x$ & & \\
\hline Rosa 'Alchemist' & 4 & & $x$ & $x$ & $x$ & & \\
\hline Rosa 'Alexandre Girault' & $9^{* *}$ & & & & $x$ & $x$ & $\mathrm{x}$ \\
\hline Rosa'Aloha' & 6 & & $x$ & $x$ & $x$ & $x$ & $x$ \\
\hline
\end{tabular}




\begin{tabular}{|c|c|c|c|c|c|c|c|}
\hline \multirow[t]{2}{*}{ Name } & \multirow[t]{2}{*}{ Rating } & \multirow[t]{2}{*}{ Pests and diseases } & \multicolumn{5}{|c|}{ Flowering period } \\
\hline & & & Oct & Nov & Dec & Jan & Feb \\
\hline Rosa'Amadis' & $8^{* * *}$ & & $x$ & $x$ & & & \\
\hline Rosa'Anaïs Ségalas' & $9^{* *}$ & $25 \%$ black spot in late Jan & $x$ & $x$ & & & \\
\hline Rosa'Anemone' & 5 & & & $x$ & & & \\
\hline Rosa 'Ann Endt' & $8^{* * *}$ & & & $x$ & $x$ & & \\
\hline Rosa Apricot Scentasia & 2 & $50 \%$ black spot in early Oct & $x$ & $x$ & & & \\
\hline Rosa Arabella & 6 & & $x$ & $x$ & & & \\
\hline Rosa 'Archiduc Joseph' & $9^{* *}$ & & $x$ & $x$ & $x$ & $x$ & \\
\hline Rosa'Astra Desmond' & $8^{* * *}$ & & & & & & \\
\hline Rosa 'Australia Felix' & 6 & $20 \%$ black spot in late Jan & $x$ & $x$ & $x$ & $x$ & \\
\hline Rosa Avalanche & DNR & & & $x$ & $x$ & $x$ & $x$ \\
\hline Rosa 'Ayrlies' & 5 & $20 \%$ black spot in late Jan & & $x$ & $x$ & & \\
\hline Rosa 'Baby Faurax' & 7 & $50 \%$ black spot in late Jan & & $x$ & & & \\
\hline Rosa'Ballerina' & 6 & $100 \%$ black spot in late Jan & & $x$ & $x$ & $x$ & \\
\hline Rosa Balmain Climber & $8^{* * *}$ & & $x$ & $x$ & $x$ & $x$ & \\
\hline Rosa banksiae 'Alba Plena' & $8^{* * *}$ & & $x$ & $\mathrm{x}$ & & & \\
\hline Rosa banksiae 'Lutea' & $8^{* * *}$ & & $x$ & $x$ & $x$ & & \\
\hline Rosa 'Bantry Bay' & 7 & & $x$ & $x$ & $x$ & & \\
\hline Rosa Beach Baby & 6 & & & $x$ & $x$ & $x$ & $x$ \\
\hline Rosa'Belle de Crécy' & 7 & & & $x$ & $x$ & & \\
\hline Rosa'Belle Poitevine' & 7 & & $x$ & $x$ & & & \\
\hline Rosa'Bert Mulley' & 7 & $75 \%$ black spot in late Jan & $x$ & $\mathrm{x}$ & $x$ & $x$ & \\
\hline Rosa 'Black Boy' & 5 & & $x$ & $x$ & & & \\
\hline Rosa Blackberry Nip & DNR & $50 \%$ powdery mildew in late Jan & & $x$ & $x$ & $x$ & $x$ \\
\hline Rosa'Blush Noisette' & 6 & $20 \%$ black spot in late Jan & $x$ & $x$ & & & \\
\hline Rosa Bright as a Button & $8^{* * *}$ & & $x$ & $x$ & & & \\
\hline Rosa Brilliant Pink Iceberg & 7 & & $x$ & $x$ & $x$ & $x$ & $x$ \\
\hline Rosa'Buff Beauty' & 7 & & $x$ & $x$ & $x$ & & \\
\hline Rosa Burgundy Iceberg & DNR & & $x$ & $x$ & $x$ & $x$ & $x$ \\
\hline Rosa Canterbury & DNR & & & $x$ & & & \\
\hline Rosa'Cécile Brunner' & $8^{* * *}$ & & $x$ & $x$ & $x$ & $x$ & \\
\hline Rosa 'Céline Forestier' & 6 & & $x$ & $x$ & & $x$ & $x$ \\
\hline Rosa'Chanelle' & 6 & & & & & & \\
\hline Rosa 'Charles de Mills' & 7 & & $x$ & $x$ & & & \\
\hline Rosa 'Cherokee Latham' & $8^{* * *}$ & & $x$ & $x$ & & & \\
\hline Rosa'Chevy Chase' & $8^{* * *}$ & & & $x$ & $x$ & & \\
\hline
\end{tabular}




\begin{tabular}{|c|c|c|c|c|c|c|c|}
\hline \multirow[t]{2}{*}{ Name } & \multirow[t]{2}{*}{ Rating } & \multirow[t]{2}{*}{ Pests and diseases } & \multicolumn{5}{|c|}{ Flowering period } \\
\hline & & & Oct & Nov & Dec & Jan & Feb \\
\hline Rosa Chloe & 6 & $25 \%$ black spot in late Jan & & $x$ & $\mathrm{x}$ & & \\
\hline Rosa Christchurch Remembers & 7 & & & & & & \\
\hline Rosa City of Hastings & 7 & & $x$ & $x$ & $x$ & $x$ & $x$ \\
\hline Rosa 'Claire Jacquier' & $8^{* * *}$ & & $x$ & $x$ & $x$ & $x$ & \\
\hline Rosa 'Climbing Devoniensis' & 7 & & $x$ & $x$ & $x$ & & \\
\hline Rosa 'Climbing Pinkie' & $9 * *$ & & $x$ & $x$ & $x$ & $x$ & $x$ \\
\hline Rosa Cocktail & DNR & & & $x$ & & & \\
\hline Rosa Coconut Ice & 6 & & $x$ & $x$ & $x$ & $x$ & $x$ \\
\hline Rosa'Compassion' & 7 & & $x$ & $x$ & & $x$ & \\
\hline Rosa 'Comtesse du Cayla' & DNR & & $x$ & & & & \\
\hline Rosa 'Cornelia' & 5 & & $x$ & $x$ & & & \\
\hline Rosa Courage & 6 & & & & & & \\
\hline Rosa 'Crepuscule' & $9 * *$ & & & $x$ & & & \\
\hline Rosa Cupcake & DNR & & & $x$ & $x$ & & \\
\hline Rosa Cupid & DNR & & & & $x$ & $x$ & \\
\hline Rosa Darcey Bussell & DNR & & & & $x$ & $x$ & $x$ \\
\hline Rosa 'De la Grifferaie' & 6 & & $x$ & $x$ & & & \\
\hline Rosa'Delicata' & 7 & & $x$ & $x$ & & & \\
\hline Rosa'Dimples' & 5 & & $x$ & $x$ & & & \\
\hline Rosa'Dortmund' & 7 & & $x$ & $x$ & & & \\
\hline Rosa Dublin Bay & $8^{* * *}$ & & $x$ & $x$ & $x$ & $x$ & \\
\hline Rosa'Duc de Fitzjames' & DNR & & $x$ & $x$ & & $x$ & \\
\hline Rosa'Duchesse de Brabant' & DNR & & $x$ & $x$ & $x$ & $x$ & $x$ \\
\hline Rosa 'Dunwich Rose' & 7 & & $x$ & $x$ & & & \\
\hline Rosa'Dupontii' & 7 & $30 \%$ black spot in late Jan & & $x$ & $x$ & & $x$ \\
\hline Rosa Eglantyne & 7 & $25 \%$ black spot in late Jan & & $x$ & $x$ & & $x$ \\
\hline Rosa Eiffel Tower 2000 & 5 & & $x$ & $x$ & $x$ & $x$ & $x$ \\
\hline Rosa Elina & $8^{* * *}$ & & $x$ & $x$ & & & \\
\hline Rosa Everlasting Love & 6 & & $x$ & $x$ & $x$ & & \\
\hline Rosa Eye Candy & 7 & & $x$ & $x$ & $x$ & $x$ & $x$ \\
\hline Rosa Eye in the Sky & $8^{* * *}$ & & $x$ & $x$ & & & \\
\hline Rosa Eye of the Tiger & 7 & & & & & & \\
\hline Rosa Eyes for You & DNR & & $x$ & $x$ & $x$ & $x$ & $x$ \\
\hline Rosa'F J Grootendorst' & 6 & & $x$ & $x$ & $x$ & $x$ & $x$ \\
\hline Rosa'Falkland' & 6 & & $x$ & $x$ & & & \\
\hline
\end{tabular}




\begin{tabular}{|c|c|c|c|c|c|c|c|}
\hline \multirow[t]{2}{*}{ Name } & \multirow[t]{2}{*}{ Rating } & \multirow[t]{2}{*}{ Pests and diseases } & \multicolumn{5}{|c|}{ Flowering period } \\
\hline & & & Oct & Nov & Dec & Jan & Feb \\
\hline Rosa'Fantin-Latour' & $8^{* * *}$ & $25 \%$ black spot in late Jan & & $x$ & $x$ & & \\
\hline Rosa 'Felicia' & 7 & & $x$ & $x$ & $x$ & $x$ & \\
\hline Rosa Fellowship & $9^{* *}$ & & $x$ & $x$ & $x$ & $x$ & $x$ \\
\hline Rosa Fiona & 5 & & $x$ & $x$ & $x$ & $x$ & $x$ \\
\hline Rosa Fireball & 2 & & $x$ & $x$ & $x$ & $x$ & $x$ \\
\hline Rosa Flamboyance & 6 & & $x$ & $x$ & $x$ & $x$ & $x$ \\
\hline Rosa Flower Carpet Gold & $8^{* * *}$ & & $x$ & $x$ & & & \\
\hline Rosa Flower Carpet Red & $9^{* *}$ & & & $x$ & & & \\
\hline Rosa Flower Carpet Scarlet & $10^{* *}$ & & & & $x$ & $x$ & \\
\hline Rosa Fond Memories & $8^{* * *}$ & & $x$ & $x$ & $x$ & $x$ & $x$ \\
\hline Rosa For Your Eyes Only & $8^{* * *}$ & & $x$ & $x$ & $x$ & & \\
\hline Rosa 'Francis E. Lester' & 7 & & $x$ & $x$ & $x$ & $x$ & \\
\hline Rosa'Friesia' & DNR & & $x$ & $x$ & $x$ & $x$ & $x$ \\
\hline Rosa Frilly Jilly & 5 & & $x$ & $x$ & $x$ & $x$ & $x$ \\
\hline Rosa'G. Nabonnand' & $8^{* * *}$ & & & $x$ & & & \\
\hline Rosa'Général Galliéni' & 6 & & $x$ & $x$ & & & \\
\hline Rosa 'Général Schablikine' & 7 & & $x$ & $x$ & & & \\
\hline Rosa Gertrude Jekyll & 6 & & $x$ & $x$ & $x$ & $x$ & $x$ \\
\hline Rosa 'Ghislaine de Féligonde' & $8^{* * *}$ & & $x$ & $x$ & & & \\
\hline Rosa 'Golden Wings' & 6 & & $x$ & $x$ & $x$ & $x$ & \\
\hline Rosa Graham Thomas & $8^{* * *}$ & & & & & & \\
\hline Rosa 'Gruss an Aachen' & DNR & & & & $x$ & $x$ & $x$ \\
\hline Rosa Guy Savoy & 5 & & $x$ & $x$ & $x$ & $x$ & $x$ \\
\hline Rosa 'Gwen Nash' & 7 & & $x$ & $x$ & & & \\
\hline Rosa'Hansa' & $8^{* * *}$ & & $x$ & $x$ & $x$ & $x$ & $x$ \\
\hline Rosa'Henry Kelsey' & DNR & & $x$ & $x$ & & & \\
\hline Rosa Iceberg & $8^{* * *}$ & & & $x$ & $x$ & $x$ & $x$ \\
\hline Rosa Indigo Knights & $8^{* * *}$ & & $x$ & $x$ & $x$ & $x$ & \\
\hline Rosa'Irish Rich Marbled' & 5 & & & $x$ & & & \\
\hline Rosa'Isabella Sprunt' & 6 & & $x$ & $x$ & & & \\
\hline Rosa John Clare & 5 & & & $x$ & $x$ & $x$ & $x$ \\
\hline Rosa Kaiteri Gold & 7 & $25 \%$ black spot in late Jan & $x$ & $x$ & $x$ & $x$ & $x$ \\
\hline Rosa 'Karl Foerster' & 6 & & $x$ & $x$ & & & \\
\hline Rosa Kordes Robusta & 7 & Some aphids & $x$ & $x$ & & & \\
\hline Rosa'La Belle Sultane' & 7 & & $x$ & $x$ & & & \\
\hline
\end{tabular}




\begin{tabular}{|c|c|c|c|c|c|c|c|}
\hline \multirow[t]{2}{*}{ Name } & \multirow[t]{2}{*}{ Rating } & \multirow[t]{2}{*}{ Pests and diseases } & \multicolumn{5}{|c|}{ Flowering period } \\
\hline & & & Oct & Nov & Dec & Jan & Feb \\
\hline Rosa 'Lady Huntingfield' & 7 & & $x$ & $x$ & & & \\
\hline Rosa 'Lady Waterlow' & DNR & & $x$ & $x$ & $x$ & $x$ & $x$ \\
\hline Rosa'Lamarque' & DNR & & $x$ & $x$ & $x$ & $x$ & $x$ \\
\hline Rosa Lavender Dream & 7 & & & $x$ & $x$ & & \\
\hline Rosa 'Lavender Lassie' & 7 & & & $x$ & $x$ & & \\
\hline Rosa Leander & 5 & & $x$ & $x$ & & & \\
\hline Rosa Leaping Salmon & 7 & & $x$ & $x$ & $x$ & $x$ & $x$ \\
\hline Rosa Lichfield Angel & DNR & & & $x$ & $x$ & $x$ & $x$ \\
\hline Rosa Linda Campbell & DNR & & $x$ & $x$ & & & \\
\hline Rosa Little Miss Perfect & 4 & $100 \%$ black spot in late Jan & & $x$ & $x$ & $\mathrm{x}$ & $x$ \\
\hline Rosa Looking Good & DNR & & & $x$ & $x$ & $x$ & $x$ \\
\hline Rosa'Louis XIV' & DNR & & $x$ & $x$ & & & \\
\hline Rosa'Louise Odier' & 7 & & $x$ & & $x$ & & \\
\hline Rosa Love Me Do & 6 & & & $x$ & $x$ & $\mathrm{x}$ & $x$ \\
\hline Rosa Loving Memory & 5 & & $\mathrm{x}$ & $x$ & $x$ & & \\
\hline Rosa Lucetta & DNR & $20 \%$ black spot in late Jan & $x$ & $x$ & $x$ & $x$ & $x$ \\
\hline Rosa'Madame Alfred Carrière' & 7 & & $\mathrm{x}$ & $x$ & $\mathrm{x}$ & $x$ & $x$ \\
\hline Rosa'Madame Antoine Mari' & $8^{* * *}$ & & $x$ & $x$ & $\mathrm{x}$ & $x$ & \\
\hline $\begin{array}{l}\text { Rosa 'Madame Grégoire } \\
\text { Staechelin' }\end{array}$ & 4 & & $x$ & $x$ & $x$ & & \\
\hline Rosa 'Madame Hardy' & DNR & $20 \%$ black spot in late Jan & & & & & \\
\hline Rosa 'Madame Lombard' & 6 & $50 \%$ black spot in late Jan & $x$ & $x$ & & & \\
\hline Rosa'Madeleine Selzer' & 5 & & $x$ & $x$ & $x$ & & \\
\hline Rosa'Maman Cochet' & 7 & & $x$ & & & & \\
\hline Rosa'Mari Dot' & 6 & & $x$ & $x$ & & & \\
\hline Rosa'Marie Nabonnand' & 6 & & $x$ & $x$ & & & \\
\hline Rosa 'Marie Pavié' & 5 & & $x$ & $x$ & $x$ & & \\
\hline Rosa Marjorie Fair & DNR & & & $x$ & & & \\
\hline Rosa 'Marjory Palmer' & $9^{* *}$ & & & & & & \\
\hline Rosa Mary Rose & 6 & & $x$ & $x$ & $x$ & $x$ & $x$ \\
\hline Rosa 'Matt Prin' & DNR & & & $x$ & & & \\
\hline Rosa'Meg' & 6 & & $x$ & $x$ & & & \\
\hline Rosa Memorial Day & DNR & & & $x$ & $x$ & $\mathrm{x}$ & $\mathrm{x}$ \\
\hline Rosa Midnight Rambler & $8^{* * *}$ & & $x$ & $x$ & & & \\
\hline Rosa Modern Miss & 6 & & & $x$ & $x$ & $x$ & $x$ \\
\hline
\end{tabular}




\begin{tabular}{|c|c|c|c|c|c|c|c|}
\hline \multirow[t]{2}{*}{ Name } & \multirow[t]{2}{*}{ Rating } & \multirow[t]{2}{*}{ Pests and diseases } & \multicolumn{5}{|c|}{ Flowering period } \\
\hline & & & Oct & Nov & Dec & Jan & Feb \\
\hline Rosa Monticello & 7 & $50 \%$ black spot in late Jan & $x$ & $x$ & & & \\
\hline Rosa Moody Dream & 7 & & $x$ & $x$ & & & \\
\hline Rosa Moondance & 5 & & & $x$ & & & \\
\hline Rosa'Moonlight' & 7 & & $x$ & $x$ & $x$ & $x$ & $x$ \\
\hline Rosa Morning Mist & DNR & & & & & & \\
\hline Rosa'Mozart' & $9^{* *}$ & & & $x$ & $x$ & $x$ & \\
\hline Rosa 'Mrs Herbert Stevens' & 6 & $30 \%$ black spot in late Jan & & $x$ & & & \\
\hline Rosa'Mrs Inge Poulsen' & 6 & & & $x$ & & & \\
\hline Rosa'Mrs R. M. Finch' & $9^{* *}$ & & $x$ & $x$ & $x$ & $x$ & $x$ \\
\hline Rosa Munstead Wood & 6 & & & $x$ & & & \\
\hline Rosa My Josephine & DNR & & $x$ & $x$ & $x$ & $x$ & $x$ \\
\hline Rosa My Mum & $9^{* *}$ & & & & $x$ & $x$ & $x$ \\
\hline Rosa Natchez & $8^{* * *}$ & & & $x$ & $x$ & $x$ & \\
\hline Rosa Nelson Girls & 7 & & $x$ & $x$ & $x$ & $x$ & $x$ \\
\hline Rosa NZ Gardener & DNR & & & $x$ & $x$ & $x$ & $x$ \\
\hline Rosa'Old Blush' & DNR & & $x$ & $x$ & & $x$ & \\
\hline Rosa'Ormiston Roy' & 6 & & $x$ & $x$ & & & \\
\hline Rosa'Parkdirektor Riggers' & 6 & & $x$ & $x$ & $x$ & $x$ & $x$ \\
\hline Rosa Parnell Heritage & 6 & & & $x$ & & & \\
\hline Rosa'Paul Transon' & DNR & & & $x$ & $x$ & & \\
\hline Rosa 'Paul's Himalayan Musk' & DNR & & $x$ & $x$ & & & \\
\hline Rosa Pavlova & 7 & & $x$ & $x$ & & & \\
\hline Rosa'Peace' & 6 & $50 \%$ black spot in late Jan & $x$ & $x$ & & & \\
\hline Rosa 'Perle d'Or' & 6 & & $x$ & $x$ & & & \\
\hline Rosa'Phyllis Bide' & 6 & & & $x$ & $x$ & $x$ & $x$ \\
\hline Rosa Pierette & 6 & & $x$ & $x$ & & & \\
\hline Rosa Pierre de Ronsard & 5 & & & $x$ & & & \\
\hline Rosa 'Pink Grootendorst' & 6 & $30 \%$ rust & $x$ & $x$ & & & \\
\hline Rosa Pink Ice & $9^{* *}$ & & $x$ & $x$ & $x$ & $x$ & $x$ \\
\hline Rosa'Pink Perpétue' & 7 & & $x$ & $x$ & $x$ & $x$ & \\
\hline Rosa'Pompon de Paris' & DNR & & $x$ & $x$ & $x$ & & \\
\hline Rosa Princess Alexandra of Kent & 6 & & & $x$ & $x$ & $x$ & $x$ \\
\hline Rosa Princess Anne & 7 & & $x$ & $x$ & $x$ & $x$ & \\
\hline Rosa Princess of Wales & 7 & & $x$ & $x$ & $x$ & $x$ & $x$ \\
\hline Rosa Purple Pizzazz & DNR & & $x$ & $x$ & $x$ & $x$ & \\
\hline
\end{tabular}




\begin{tabular}{|c|c|c|c|c|c|c|c|}
\hline \multirow[t]{2}{*}{ Name } & \multirow[t]{2}{*}{ Rating } & \multirow[t]{2}{*}{ Pests and diseases } & \multicolumn{5}{|c|}{ Flowering period } \\
\hline & & & Oct & Nov & Dec & Jan & Feb \\
\hline Rosa 'Purple Sage' & 6 & & & $x$ & & & \\
\hline Rosa 'Queen of the Musks' & 6 & $25 \%$ black spot in late Jan & $x$ & $x$ & $x$ & $x$ & \\
\hline Rosa'Rawiri Taiwhanga' & DNR & & $x$ & $x$ & & & \\
\hline Rosa Red Flame & 6 & & $x$ & $x$ & & & \\
\hline Rosa Red Meidiland & $8^{* * *}$ & & & & & & \\
\hline Rosa 'Reine des Violettes' & 5 & $30 \%$ powdery mildew in late Jan & $x$ & $x$ & & & \\
\hline Rosa 'Restless' & 6 & & $x$ & $x$ & & & \\
\hline Rosa'Rêve d'Or' & 4 & & $x$ & $x$ & $x$ & $x$ & $x$ \\
\hline Rosa 'Rosenfest' & 7 & & & & & & \\
\hline Rosa'Rosette Delizy' & 6 & & $x$ & $x$ & & & \\
\hline Rosa'Roundelay' & 5 & & $x$ & $x$ & & & \\
\hline Rosa 'Ruby Alison' & $8^{* * *}$ & & & $x$ & & & \\
\hline Rosa Rugelda & 7 & & & $x$ & & & \\
\hline Rosa rugosa 'Roseraie de l'Hay' & $9^{* *}$ & & $x$ & $x$ & & & \\
\hline Rosa'Russelliana' & 7 & & & $x$ & & & \\
\hline Rosa'Safrano' & DNR & & & & $\mathrm{x}$ & & \\
\hline Rosa 'Sanders White' & 7 & & $x$ & $x$ & $x$ & $x$ & $x$ \\
\hline Rosa Santana & 5 & & & & & & \\
\hline Rosa Scentasia & 5 & & $x$ & $x$ & $x$ & $x$ & $x$ \\
\hline Rosa Scentimental & 6 & $25 \%$ black spot in late Jan & & $x$ & $x$ & $x$ & $x$ \\
\hline Rosa'Schoener's Nutkana' & 5 & & $x$ & $x$ & $x$ & $x$ & \\
\hline Rosa Scott Base & DNR & & $x$ & $x$ & $x$ & $x$ & $\mathrm{x}$ \\
\hline Rosa'Sea Foam' & 7 & & & $x$ & $x$ & & \\
\hline Rosa Serendipity & $9^{* *}$ & & $x$ & $x$ & $x$ & $x$ & $x$ \\
\hline Rosa 'Serratipetala' & 6 & & $x$ & & & & \\
\hline Rosa Sexy Rexy & DNR & & & & $x$ & $x$ & $x$ \\
\hline Rosa Sharifa Asma & 7 & & $x$ & $x$ & $x$ & $x$ & $x$ \\
\hline Rosa'Single Cherry' & 4 & & $x$ & $x$ & & & \\
\hline Rosa 'Sir Cedric Morris' & $8^{* * *}$ & $30 \%$ black spot in late Jan & $x$ & $x$ & & & \\
\hline Rosa Sir John Betjeman & 6 & & & & & & \\
\hline Rosa Sir Tristram & 6 & & $x$ & $x$ & & & \\
\hline Rosa 'Slater's Crimson China' & 6 & & $x$ & $x$ & $\mathrm{x}$ & & $x$ \\
\hline Rosa Social Climber & 6 & & $x$ & $x$ & & & \\
\hline Rosa'Sombreuil' & 7 & & $x$ & $x$ & $x$ & $x$ & \\
\hline Rosa'Sophie's Perpetual' & 6 & & & & & & \\
\hline
\end{tabular}




\begin{tabular}{|c|c|c|c|c|c|c|c|}
\hline \multirow[t]{2}{*}{ Name } & \multirow[t]{2}{*}{ Rating } & \multirow[t]{2}{*}{ Pests and diseases } & \multicolumn{5}{|c|}{ Flowering period } \\
\hline & & & Oct & Nov & Dec & Jan & Feb \\
\hline Rosa Sophy's Rose & 6 & & $x$ & $x$ & $x$ & $x$ & $x$ \\
\hline Rosa Souvenir de Louis Amade & 6 & & $x$ & $x$ & & & \\
\hline $\begin{array}{l}\text { Rosa'Souvenir de Madame } \\
\text { Léonie Viennot' }\end{array}$ & $8^{* * *}$ & & $x$ & $x$ & $x$ & $x$ & $x$ \\
\hline Rosa'St Hilda's Rose' & DNR & & & $x$ & & & \\
\hline Rosa St. Mary's Rose & 5 & $50 \%$ black spot in late Jan & & $x$ & $x$ & $x$ & $x$ \\
\hline Rosa Starship & $8^{* * *}$ & & & $x$ & $x$ & $x$ & \\
\hline Rosa'Suitor' & DNR & & & & $x$ & & \\
\hline Rosa Summer Passion & $9^{* *}$ & $20 \%$ black spot in late Jan & & & $x$ & $x$ & $x$ \\
\hline Rosa Summer Wine & 6 & & $x$ & $x$ & & & \\
\hline Rosa Surrey & 7 & & & & & & \\
\hline Rosa Swany & DNR & & $x$ & & & & \\
\hline Rosa'Tea Rambler' & DNR & & & $x$ & & & \\
\hline Rosa Teasing Georgia & DNR & & & $x$ & & & \\
\hline Rosa 'The Active' & 6 & & $x$ & $x$ & $x$ & $x$ & $x$ \\
\hline Rosa The Alexandra Rose & 7 & & $x$ & $x$ & & & \\
\hline Rosa'The Bishop' & 6 & & $x$ & $x$ & & & \\
\hline Rosa The Chelsea Rose & 6 & & $x$ & $x$ & & & \\
\hline Rosa The Dark Lady & DNR & $50 \%$ powdery mildew in late Jan & & $x$ & $x$ & $x$ & $x$ \\
\hline Rosa'The Fairy' & $9^{* *}$ & & & & $x$ & $x$ & $x$ \\
\hline Rosa The Wedgwood Rose & 6 & & & $x$ & $x$ & $x$ & \\
\hline Rosa'Topaz Jewel' & 7 & & $x$ & $x$ & & $x$ & \\
\hline Rosa Tropical Delight & $9^{* *}$ & & & $x$ & $x$ & $x$ & $x$ \\
\hline Rosa Uetersen & $8^{* * *}$ & & $x$ & $x$ & $x$ & $x$ & $x$ \\
\hline Rosa'Vanity' & 7 & & $x$ & $x$ & $x$ & $x$ & $x$ \\
\hline Rosa'Veilchenblau' & 5 & $30 \%$ black spot in late Jan & & & & & \\
\hline Rosa Warm Wishes & $8^{* * *}$ & $20 \%$ black spot in late Jan & & $x$ & $x$ & $x$ & \\
\hline Rosa'Wedding Day' & $8^{* * *}$ & & & $x$ & $x$ & & \\
\hline Rosa Westerland & $8^{* * *}$ & & & $x$ & $x$ & & \\
\hline Rosa'White Cockade' & 5 & & $x$ & $x$ & & & \\
\hline $\begin{array}{l}\text { Rosa'White Duchesse de } \\
\text { Brabant' }\end{array}$ & 5 & & $x$ & $x$ & & & \\
\hline Rosa White Romance & 6 & & $x$ & $x$ & $x$ & $x$ & $x$ \\
\hline Rosa 'White Sparrieshoop' & 7 & & & & & & \\
\hline Rosa'Wickwar' & $8^{* * *}$ & & $x$ & $x$ & & & \\
\hline Rosa Wild Cherry & $8^{* * *}$ & & $x$ & $\mathrm{x}$ & $\mathrm{x}$ & $x$ & $x$ \\
\hline
\end{tabular}




\begin{tabular}{|l|l|l|c|c|c|c|c|}
\hline \multirow{2}{*}{ Name } & Rating & \multicolumn{2}{|c|}{ Pests and diseases } & \multicolumn{4}{c|}{ Flowering period } \\
\cline { 4 - 7 } & & & Oct & Nov & Dec & Jan & Feb \\
\hline Rosa'William Baffin' & 6 & & & $\mathrm{x}$ & $\mathrm{x}$ & $\mathrm{x}$ & $\mathrm{x}$ \\
\hline Rosa'William Lobb' & 6 & & & & $\mathrm{x}$ & \\
\hline Rosa'Wind Chimes' & DNR & & & & & & \\
\hline Rosa Windermere & DNR & & & $\mathrm{x}$ & $\mathrm{x}$ & $\mathrm{x}$ & $\mathrm{x}$ \\
\hline Rosa'Yesterday' & 6 & & & & & & \\
\hline Rosa'Yvonne Rabier' & 6 & & $\mathrm{x}$ & $\mathrm{x}$ & $\mathrm{x}$ & $\mathrm{x}$ & $\mathrm{x}$ \\
\hline
\end{tabular}

